\title{
HEALTH COVERAGE FOR WORKERS IN EGYPT
}

\author{
By \\ Abo El-Ata GA \\ Department of Occupational and Environmental Medicine \\ Cairo University- Cairo (Egypt)
}

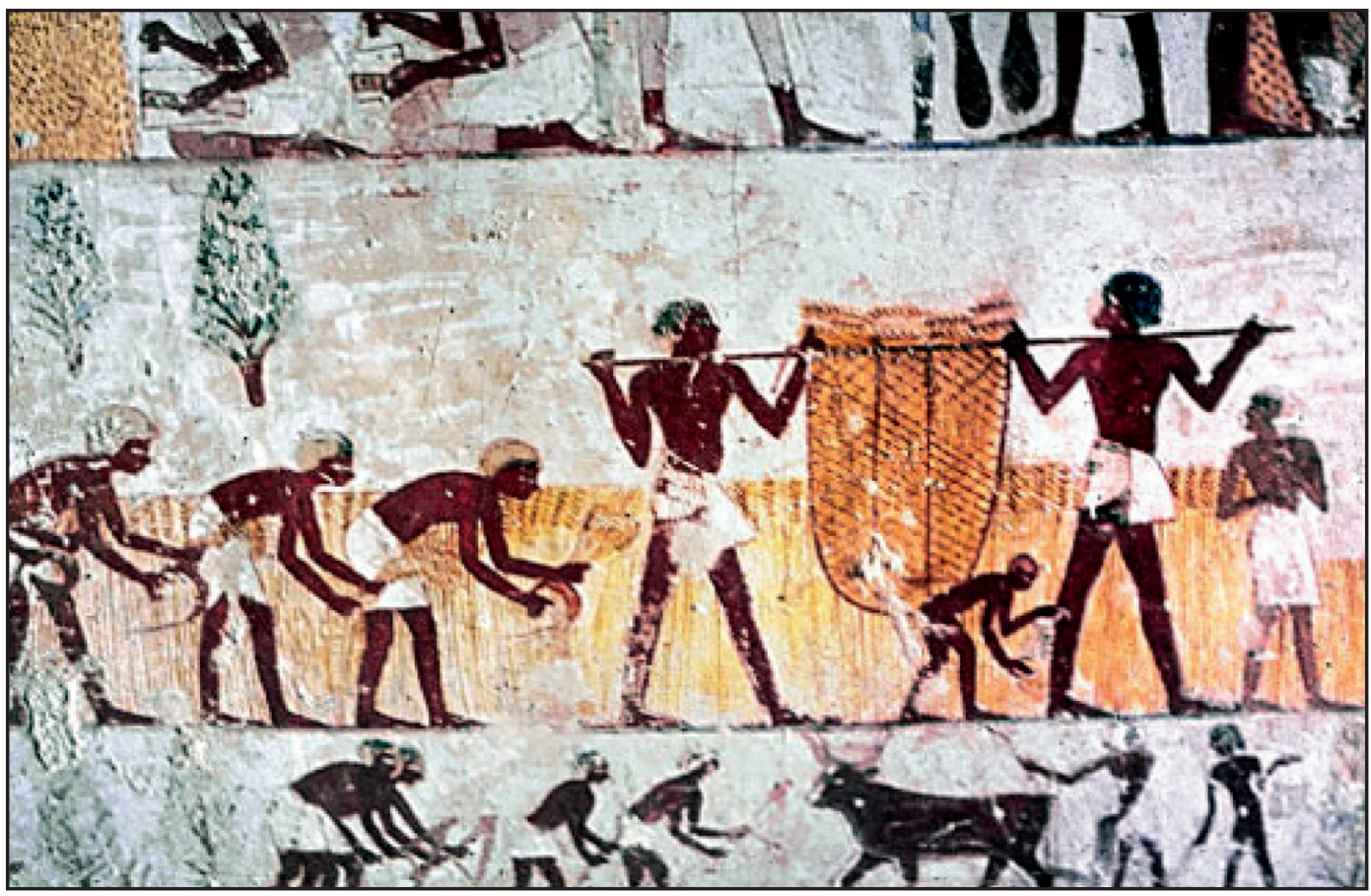

Figure 1: "During the seven years of abundance the land produced plentifully" (Gn 41:47). Egyptian workers harvesting grain and carrying it away to be threshed. Tomb of Mena, Thebes, ca. 1420 B.C. ABR File photo. 


\begin{abstract}
:
This study aims at discussing the extent of covering the Egyptian employees with the basic/ essential occupational healthcare services. The paper detailed the legislative, institutional and technical aspects relevant to various $\mathrm{OCH}$ services, emphasizing the central role of Primary Healthcare (PHC) services and the Health Insurance Organization (HIO). The natural history of developing the public healthcare system in Egypt is revealed, in details, showing its objectives, procedures and categories/ leveling. The study illustrates the overall picture of healthcare services pertinent to Egyptian workers at present; the strengths, weaknesses and recommendations aiming at comprehensive and integrated coverage in order to comply with the international conventions and the national legislative framework.

The study concluded that $\mathrm{OCH}$ services are essentially necessary for the Egyptian labor force that constitutes about $31.7 \%$ of the whole population and about $48.84 \%$ of those aged $15 \mathrm{yrs}$. or more. There is an urgent need of expanding the OCH services, which currently cover about one-quarter of the working population, to provide every employee with the basic $\mathrm{OCH}$ services as indicated by the international recommendations and the Egyptian Constitution, legislation and community necessity.
\end{abstract}

Key words: occupational healthcare services, universal coverage, working population, Egypt

\section{Introduction}

More than 200 years elapsed since the first legislation had been issued to protect young workers against a defined workplace risk. Since then a number of acts including sections dealing with health and welfare of factory workers followed. Employment of workers, employment conditions and agencies competent with occupational safety and health as well as penalty clauses were covered by Act No. 91, the first comprehensive Labour Law, adopted on 5 April 1959.
Regulations developed and expanded gradually in order to cover all hazards and economic sectors. It should be noted that the Egyptian legislation related to Occupational Safety and Health (OSH) was extensively up-dated in July 2003, as described in chapter II. It now covers a great part of the requirements and provisions entailed in major ILO Conventions related to occupational safety and health.

Implementation bodies are thoroughly dealt with in chapter III. Their strengthening should be analyzed in the light of the best possible use 
of already existing structures and of feasible ways to improve their functions on a sustainable basis.

Education, training and information mechanisms and institutions play a vital role in the progressive construction of a national Occupational Health $(\mathrm{OCH})$ system. These are essential tools in the process of awareness-raising on hazards and preventive action at all levels and, considering the needs of the country in this respect, they should be given top priority.

The active involvement and participation of employers and workers in the development of a strong health and safety culture should never be forgotten. Special activities aimed at these target groups could be envisaged. In Egypt, a country where micro and small and medium sized enterprises, together with agriculture, employ a very large percentage of the working population, identifying priorities for the development of a national $\mathrm{OCH}$ action program is crucial.

This paper aims at discussing the extent of covering the Egyptian working population with the basic/ essential occupational healthcare services. It illustrates the overall picture of healthcare services pertinent to Egyptian workers at present; the strengths, weaknesses and a plan of action aiming at comprehensive and integrated coverage in order to comply with the international conventions and the national legislative framework.

\section{Historic perspective}

The earliest legislation pertaining to occupational health in Egypt dated back to July 1809 . It dealt with employment of children in cotton ginning factories. Eighteen years later, the first medical school was launched at the Abu-Zaabal suburbs, about $20 \mathrm{Km}$ to the north-east of Cairo, which was moved, 10 years later, to its location, till now, in the center of Cairo, at Kasr El-Aini Palace that was built at the 15 th century by Amir (= Prince) Ahmed Ben El-Aini, one of the famous Mamlouks, during the medieval period. Seventeen years later, the first 'bylaws' organizing the healthcare services had been issued by the same Governor of Egypt: Mohamed Ali Pacha, who was behind issuance of the earlier decrees. The first constitutional rights to healthcare were declared in the 1923 constitution. Thirteen years later, re-organization of the healthcare services necessitated launching, for the first time, 'the Ministry of Public 
Health' which started an ambitious plan to build hundreds of healthcare units and polyclinics that constitute the corner stone of the 'Primary healthcare services' few years later. Establishing a 'Multi- level healthcare system' got a powerful drive after the 1952 revolution, through building hundreds of primary healthcare units, hundreds of hospitals in the villages, districts, as well as public, specialized and university hospitals. A year ago, the government of Egypt agreed on adding 17 new occupational diseases to be covered under Egypt's social health insurance law 79/ 1975. This came in response to demands made by the ministers of Manpower and Immigration, and Health and Population, after the decision was ratified by the Board of Directors of the National Authority for Social Insurance. (Abo El-Ata and Nahmias, 2005, Amendment to Table 1 annexed to Law 79/ 1975). Box1 illustrates the main marks along the healthcare development in Egypt.

\section{Box 1: The main marks along the healthcare development in Egypt}

1809 .. Decree on prohibition of child work at cotton ginneries

1827 .. Establishing Kasr Al-Aini medical school;

1844 .. Bylaws organizing healthcare services;

1923 .. Constitutional rights to healthcare in the 1923 constitution;

1936 .. Launching the Ministry of Public Health;

1948 .. UN Declaration on Human Rights including Right to healthcare;

1956 .. Establish the High Institute of Public Health in Alexandria, with academic and applied functions,

1956 .. Establish the National Research Center in Giza, with academic and applied functions, emphasizing basic and advanced studies,

1959 .. Issuance of Labour Law 91/ 1959 with a Chapter on 'Industrial safety' issues and another Chapter on Social and cultural benefits for employees,

1959 .. Issuance of Social Insurance Law 92/ 1959 with Chapters on 'Health Insurance' benefits for employees,

1964 .. Establish the "Health Insurance Organization" to provide a wide-based Basic Benefit Package for various employees,

1969 .. Establish the National institute of Occupational safety and Health- NIOSH, for executing research, training, and technical consultancy,

1981 .. Issuance of Labour Law 137/ 1981 with a more comprehensive Chapter on 'Occupational safety and Health' issues,

1993 .. Establish supreme committee to control infectious dis.

2003 .. Issuance of the Unified Labour Law 12/ 2003 with a more advanced and comprehensive Book on 'Occupational safety and Health' issues,

2013 .. Modification of the national Schedule of Occupational Diseases to comply with the 2010modified ILO list of Occupational Diseases,

2014 .. Draft amendments on Labour Law No. 12/ 2003 to include provisions in the ILO Conventions and Recommendations. 


\section{Egypt Population and Labor-force}

The population estimate at January 2014 is 85,783 thousand, of whom 43,796 thousand males $(51.1 \%)$ and 41,987 thousand females (48.9\%). About $42.8 \%$ of the population is currently living in urban areas, while $57.2 \%$ are living in rural areas. About $31.1 \%$ aged $0-14$ years, $64.5 \%$ aged 15 64 years and $4.4 \%$ aged 65 years and above (CAPMAS, 2014).

The total Labor force in Egypt is last measured at 27.193.916, according to the Central Agency for Public Mobilization and statistics (CAPMAS, 2014). It comprises people ages 15 and older who meet the International Labour Organization definition of the economically active population: all people who supply labor for the production of goods and services during a specified period. It includes both the employed and the unemployed. While national practices vary in the treatment of such groups as the armed forces and seasonal or part-time workers, in general the labor force includes the armed forces, the unemployed and first-time job-seekers, but excludes households and other unpaid caregivers and workers in the informal sector.

The present estimate of the Egyptian labor force, developed along the last quarter of this century from nearly 16 million to the present figure: $\approx 27.2$ million (Table 1 and figure 2). 
Table 1 and figure 2: 25 years' development of Egypt labor force

\begin{tabular}{|c|c|}
\hline Year & Value \\
\hline 2012 & 27.193 .916 \\
\hline 2011 & 26.585 .338 \\
\hline 2010 & 25.986 .819 \\
\hline 2009 & 25.348 .543 \\
\hline 2008 & 24.773 .710 \\
\hline 2007 & 24.149 .082 \\
\hline 2006 & 23.118 .796 \\
\hline 2005 & 23.105 .750 \\
\hline 2004 & 22.191 .651 \\
\hline 2003 & 21.182 .263 \\
\hline 2002 & 20.234 .194 \\
\hline 2001 & 19.976 .065 \\
\hline 2000 & 19.687 .527 \\
\hline 1999 & 19.377.289 \\
\hline 1998 & 18.354 .014 \\
\hline 1997 & 18.136 .300 \\
\hline 1996 & 17.926 .634 \\
\hline 1995 & 17.720 .373 \\
\hline 1994 & 17.740 .922 \\
\hline 1993 & 17.029 .122 \\
\hline 1992 & 16.484 .237 \\
\hline 1991 & 16.545 .813 \\
\hline 1990 & 17.035 .841 \\
\hline
\end{tabular}

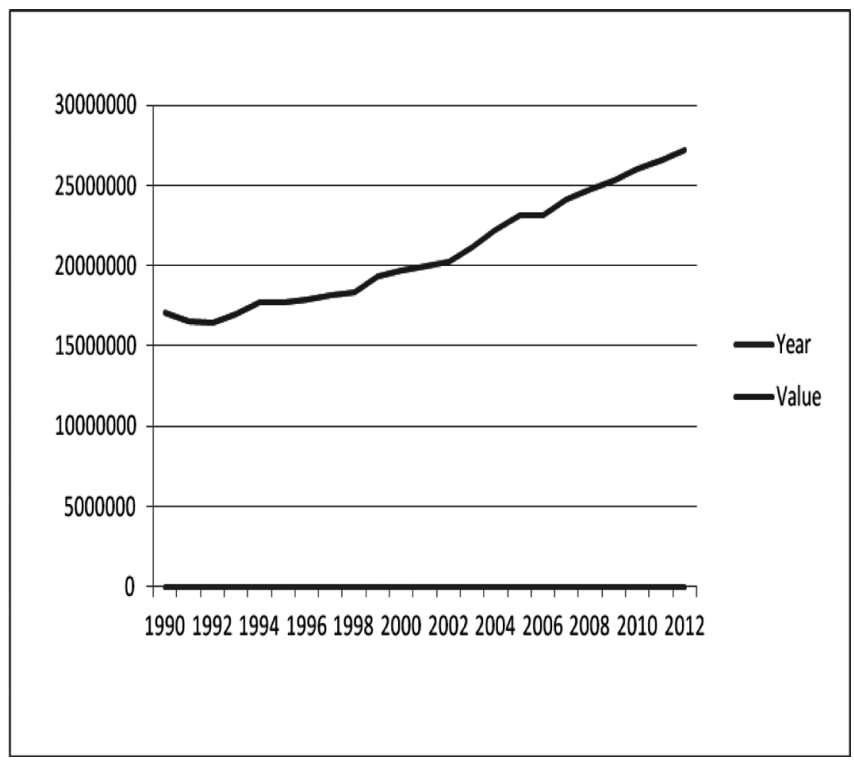

Source: CAPMAS (2014). Egypt in Figures 2014.

The following Box 2 illustrates some important figures on the employment structure in Egypt. 


\section{Box 2: Some important figures on the employment structure in Egypt (CAPMAS, 2014)}

Labor force at January 2014:

- $\quad 27.2$ million ( $\approx 31.7 \%$ of Egypt population, and $48.84 \%$ of those aged 15 years + );

- Labor-force participation: females $22.7 \%$, males $77.3 \%$ aged $15 \mathrm{yrs}+$

- Urban $41.8 \%$, Rural $58.2 \%$

- $\quad$ Employed (87.3\%): 23,596 million; females $19.8 \%$, males $80.2 \%$ aged $15 \mathrm{yrs}+$

- Unemployed (12.7\%): 3,425 million; 1,483 females and 1,942 males

- $\quad$ Employment to population ratio:

- Ages $25+$ yrs. $51.3 \%$,

○ ages $15-24$ yrs. $54.1 \%$,

○ ages 05-14 yrs. 07.0\%.

- $\quad$ Employed $42.8 \%$ in formal activities, while 58.2\% in informal activities.

- $\quad$ Employed according to major economic activities (International Youth Foundation, 2013)

- $27.1 \%$ in agriculture and fishing,

- $24.9 \%$ in manufacturing industry, metallurgical and construction

- $48.0 \%$ in services and trade.

- $\quad$ Employed in the Government: 5,219 million (22.1\%), in the Public sector and Public Business sector: 0.871 million (3.7\%), and in Private sector: 17,506 million (74.2\%).

Total dependency ratio $=52.9$ (in 100 people ages $15-64$ )

Economic facilities:

- $\quad>40,000$ large and medium- scale enterprises,

○ $\quad 2.9-4.4$ million small and ultra-small enterprises- registered and unregistered. 
Table 2: Figures on population and labor force and world rank

\begin{tabular}{|l|l|l|l|l|}
\hline Comparison & $\begin{array}{l}\text { Rank - } \\
\text { world }\end{array}$ & Value & Date & Source \\
\hline Population, total & 16 & $85,783,117$ & 2014 & CAPMAS \\
\hline Area (sq. km) & 29 & $1.001 .450,0$ & 2011 & Worldbank \\
\hline $\begin{array}{l}\text { Gross domestic product in exchange } \\
\text { rates (US \$) }\end{array}$ & 41 & 262.000 .000 .000 & 2013 & $\begin{array}{l}\text { World } \\
\text { Factbook }\end{array}$ \\
\hline $\begin{array}{l}\text { Gross domestic product per capita } \\
\text { (US\$) }\end{array}$ & 135 & 3,256 & 2012 & Worldbank \\
\hline Labor force & 20 & 27.021 .512 & 2014 & CAPMAS \\
\hline $\begin{array}{l}\text { Labor force, female (\% of total labor } \\
\text { force) }\end{array}$ & 168 & 24,2 & 2012 & Worldbank \\
\hline $\begin{array}{l}\text { Labor force with primary education } \\
\text { (\% of total) }\end{array}$ & 117 & 10,4 & 2011 & Worldbank \\
\hline $\begin{array}{l}\text { Labor force with primary education, } \\
\text { female (\% of female labor force) }\end{array}$ & 124 & 3,7 & 2011 & Worldbank \\
\hline $\begin{array}{l}\text { Labor force with primary education, } \\
\text { male (\% of male labor force) }\end{array}$ & 112 & 12,3 & 2011 & Worldbank \\
\hline $\begin{array}{l}\text { Labor force with secondary education, } \\
\text { female (\% of female labor force) }\end{array}$ & 74 & 35,4 & 2011 & Worldbank \\
\hline $\begin{array}{l}\text { Labor force with secondary education, } \\
\text { male (\% of male labor force) }\end{array}$ & 72 & 37,7 & 19,2 & Worldbank \\
\hline $\begin{array}{l}\text { Labor force with tertiary education }(\% \\
\text { of total) }\end{array}$ & 74 & 48 & 29,1 & Worldbank \\
\hline $\begin{array}{l}\text { Labor force with tertiary education, } \\
\text { female (\% of female labor force) }\end{array}$ & 70 & 16,3 & Worldbank \\
\hline $\begin{array}{l}\text { Labor force with tertiary education, } \\
\text { male (\% of male labor force) }\end{array}$ & 4011 & World bank \\
\hline
\end{tabular}

Source: Central Agency for Public Mobilization and Statistics- CAPMAS (2014). Egypt in Figures 2014. Issued in March 2014, CAPMAS at Cairo- Egypt; and World Bank (2013): Labor force - total in Egypt - Trading Economics.

In: www.tradingeconomics.com/egypt/labor-force-total-wb-data.html.

Table 2 illustrates few figures on population and labor force in respect to the world rank. 


\section{Legislative framework}

Article 13 of the new Constitution, issued in January 18th, 2014 stated on the state responsibility on providing the labor force with security, safety and health requirements in their workplaces. In addition, the Constitution tackled the following basic elements:

- The central role of the healthcare authorities (especially for poor),

- The "therapeutic" and "preventive" health services,

- Health of special groups: Children; Women; Workers, those with special needs.

The Labor Law No. 12/ 2003 stipulates that the employer takes all necessary measures to ensure safety and health at the workplace in particular with regard to mechanical, physical, chemical and biological hazards (article 208). The law also requires the medical examination of the worker before employment, i.e. pre-placement (article 216), first aid measures, medical attention and treatment depending on the number of workers employed (art. 220), and also periodic medical examination of those workers who are exposed to the risk of any occupational diseases (art.219) annexed to the Social Insurance Law No. 79/ 1975 and amendments (see table 3 below). Employers shall inform workers of the dangers they are exposed to in case of non-observance of protective measures and shall provide them with personal protective equipment (art. 208 - 215) (Abo El-Ata and Nahmias, 2005). 
Table 3: The List of Occupational Diseases annexed to the Law No. 79/ 1975 and its amendments.

\begin{tabular}{|c|c|c|}
\hline $\begin{array}{l}\text { 1. Lead poisoning and sequels } \\
\text { 2. Mercury poisoning and } \\
\text { sequels } \\
\text { 3. Arsenic poisoning and sequels } \\
\text { 4. Antimony poisoning and } \\
\text { sequels } \\
\text { 5. Phosphorus poisoning } \\
\text { and sequels } \\
\text { 6. Benzol } \\
\text { poisoning and sequels } \\
\text { 7. Manganese poisoning } \\
\text { and sequels } \\
\text { 8. Sulphur poisoning and } \\
\text { sequels } \\
\text { 9. Chromium ulcers and } \\
\text { sequels } \\
\text { 10. Nickel ulcers and sequels } \\
\text { 11. Noxious gases' poisoning } \\
\text { 12. Cyanide poisoning and } \\
\text { sequels } \\
\text { 13. Poisoning by Halogens } \\
\text { and sequels } \\
\text { 14. Poisoning by Petroleum } \\
\text { and gases } \\
\text { 15. Poisoning by Chloroform } \\
\text { and carbon tetrachloride } \\
\text { 16. Poisoning by Aliphatic } \\
\text { hydrocarbons and other } \\
\text { halides } \\
\text { 17. Pathological } \\
\text { of Radium and other } \\
\text { ionizing radiation. } \\
\text { 18. Primary skin cancer and } \\
\text { chronic inflammation and } \\
\text { ulcers to skin and eyes } \\
\text { (talcosis), cotton dust } \\
\text { 19. Effects due to heat and cold } \\
\text { 20. Pulmonary Dust Diseases } \\
\text { (Pneumoconiosis) due } \\
\text { asilica (silicosis), } \\
\text { (B) }\end{array}$ & $\begin{array}{l}\text { 21. Anthrax } \\
\text { 22. Glanders } \\
\text { 23. Tuberculosis } \\
\text { 24. Infectious disease in } \\
\text { hospitals and HCFs, as } \\
\text { well as in other sites } \\
\text { 25. Beryllium poisoning and } \\
\text { sequels } \\
\text { 26. Selenium poisoning and } \\
\text { sequels } \\
\text { 27. Diseases and } \\
\text { manifestations due to } \\
\text { abnormal barometric } \\
\text { pressure } \\
\text { 28. Diseases and } \\
\text { manifestations due to } \\
\text { exposure to hormones } \\
\text { 29. Occupational noise- } \\
\text { induced hearing loss } \\
\text { (deafness) } \\
\text { 30. Segmental body } \\
\text { Vibrations affecting } \\
\text { upper limbs' hands and } \\
\text { wrists } \\
\text { 31. Poisoning by nitrates, } \\
\text { nitrites, and nitro- } \\
\text { glycerine and salts of } \\
\text { nitric acid } \\
\text { 32. Cadmium poisoning and } \\
\text { sequels } \\
\text { 33. Poisoning by alcohols, } \\
\text { glycols, ketons and their } \\
\text { different types and sequels } \\
\text { 34. Diseases resulting from } \\
\text { non-ionizing radiations, } \\
\text { e.g. ultraviolet and infra- } \\
\text { red } \\
\text { 35. Poisoning by pesticides } \\
\text { 36. Acrylamide and } \\
\text { acrylonitrile } \\
\text { ald }\end{array}$ & 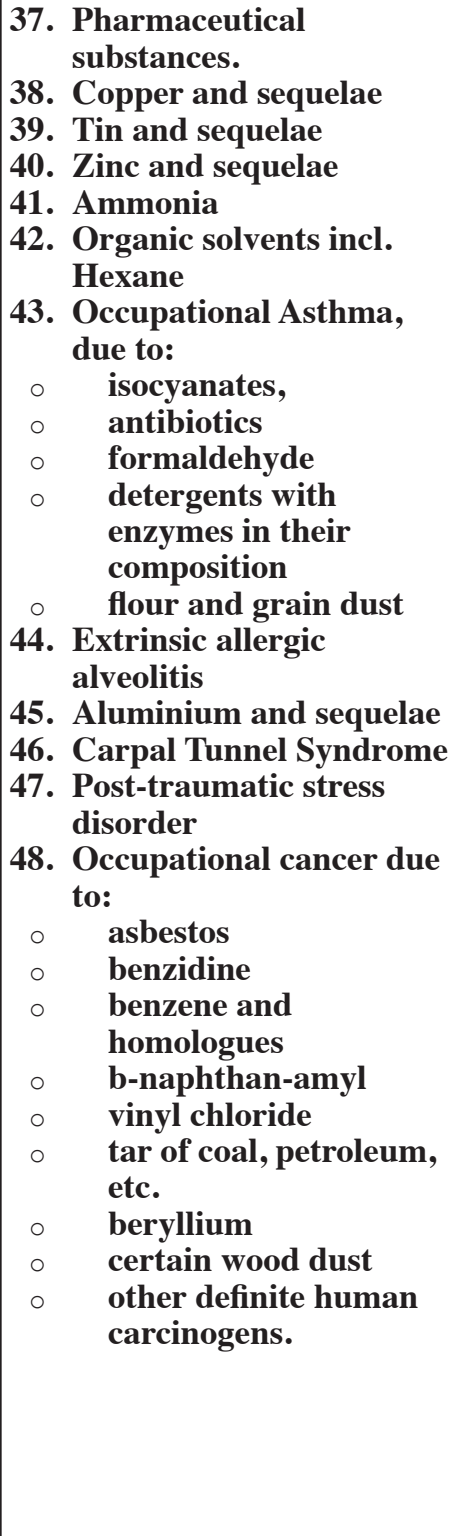 \\
\hline
\end{tabular}

Source: Extracted from: Annexl to the Law No. 79/ 1975 on Social Insurance and amendments

(Table 1 annexed to Law 79/ 1975) 
Law No. 27/1981 concerning "Employment of Workers in Mining and Quarrying Activities": Title 4 of part II (Work Organization and Regulation) requires pre-placement examination and periodic medical examinations every 6 months for workers exposed to dust, including a chest $\mathrm{X}$ ray. Part II deals with working hours, sick leave, safety measures, health \& social care, retirement, inspection and others. Moreover the Minister of Health issued 3 Decrees (59/ 1997, 283/ 1997 \& 215/1998) and designated a committee of 5 members for reading, and diagnosing radiographs of workers exposed to dust \& fibrous minerals in mines, quarries and specific remote areas. Out of more than 12.000 radiographs, 5.000 cases of pneumoconiosis were diagnosed and workers were accordingly compensated for disability.

Law No. 59/1960 on protection against ionizing radiation regulates licensing and use of radiation sources. Open sources are the responsibility of the Atomic Energy Organization (AEO). The Ministry of Health and Population (MOHP) is responsible for closed sources and X-ray machines and specifies qualifications and training of personnel using them. Both bodies
(AEO and MOHP) inspect places with radiation sources and keep absorbed radiation doses and medical records of all exposed workers.

Law 79/1975, the Social (and Health) Insurance Law as amended by Law No. 25 (1977) is implemented by the Ministry of Insurance and Social Affairs. Its objective is to provide benefits for old age (including disability and death), illness, unemployment, work-related injuries (victims of occupational accidents and diseases or overexertion at the workplace) and social care (covering maternity). The social insurance scheme, Law 79, applies to all civil servants in government and public sector services, with no age limit; workers in public institutions and public sector units, regardless of age; and workers with regular employment in the private sector, who are over 18 years of age. Its coverage was extended in 1976 to small employers and the selfemployed (Law 108/1976); to Egyptian workers abroad (Law 50/1978); and to temporary workers (Law 112/1980). Employees in the Government and public sectors aged 16 and over, and in the private sector, aged 18 and over, are insured against the consequences of employment-related injuries or 
occupational diseases. Domestic servants are not covered; in addition, agricultural workers and artisans in practice fall outside the scope of the law. Compensation occurs for diseases listed in the schedule of occupational diseases, in case of injury resulting from accident at work, or because of work, or due to a commuting accident.

\section{Institutional/ organizational Framework}

Primary Health Care (PHC) services are essentially aiming at the following:

- Prevention of epidemics and the spread of disease,

- Protection against environmental hazards,

- Prevention of injuries,

- Promotion and encouragement of healthy behaviors,

- Response to disasters and assists communities in recovery, and

- Assuring the quality and accessibility of health services.

Much of these objectives are coinciding with those of basic $\mathrm{OCH}$ services and even the procedures and accessibility of target personnel are similar.
The "Essential Services of Primary Healthcare" include:

1. Monitor health status to identify and solve community health problems

2. Diagnose and investigate health problems and health hazards in the community

3. Inform, educate, and empower people about health issues

4. Mobilize community partnerships to identify and solve health problems

5. Develop policies and plans that support individual and community health efforts

6. Enforce laws and regulations that protect health and ensure safety

7. Link people to needed personal health services and assure the provision of health care when otherwise unavailable

8. Assure a competent public and personal health care workforce

9. Evaluate effectiveness, accessibility, and quality of personal and population-based health services

10. Research for new insights and innovative solutions to health problems 
Basically, any public health activity, including $\mathrm{OCH}$ activities, can fit into one of these ten categories. So for example, Essential Service \#1 includes activities such as data collection, community health assessments and the maintenance of employee's health registries. As another example, Essential Service \#7 includes personal health care services as well as transportation and other enabling services and assuring the availability of culturally appropriate personnel and materials (Arnaout, 2006).
Primary Healthcare Services (Not including: health offices, child and mother care centers, district clinics, or comprehensive clinics), are accessible in 253 administrations in 27 governorates (1 - 26 admin/ gov.), through 4490 primary healthcare units, centers, clinics, etc. The units are distributed in rural areas (3936 in number, representing $87.7 \%$ of all primary healthcare units), and in urban areas (554 in number, representing 12.3\%). Table 4, illustrates various categories of Primary Healthcare Services.

\section{Table 4: Various categories of Primary Healthcare Services}

\begin{tabular}{|l|c|c|}
\hline 1ry HC services & No. & \% \\
\hline Family health units & 1,694 & 37.7 \\
\hline Family health centers & 250 & 5.6 \\
\hline Rural health units & 2,242 & 49.9 \\
\hline Medical centers & 304 & 7.6 \\
\hline Total & $\mathbf{4 , 4 9 0}$ & $\mathbf{2 1 0 0 . 0}$ \\
\hline
\end{tabular}

Source: The National Information Center for Health and Population (2014)

Primary Healthcare Services are the frontline of healthcare services all over the country. Their mandate could be summarized as follows:

Manage the vast majority of cases, those need simple investigations and treatment,
Refer difficult cases to district, public, specialized and university hospitals,

Refer cases with suspected occupational etiology to HIO Centers and Hospitals 
Primary Healthcare units and centers provide their services by a workforce of about 104,817 healthcare personnel, categorized as follows:

- 12,853 Physicians

- 7,344 Dentists

- 8874 Pharmacists

- 46,359 Nurses

- 10,889 Technicians

- 18,498 others
$12.3 \%$

$07.0 \%$

$08.5 \%$

$44.2 \%$

$10.4 \%$

$17.6 \%$
Secondary and Tertiary Healthcare Services are accessible through district, public, specialized and university hospitals, as well as the 'Health Insurance Organization's Centers and Hospitals'. The number and capacity of these hospitals are illustrated in table 5, below.

Table 5: The number and capacity of government- related secondary and tertiary healthcare services in Egypt

\begin{tabular}{|l|c|c|c|c|}
\hline \multirow{2}{*}{ Category } & \multicolumn{2}{|c|}{ Hospitals } & \multicolumn{2}{c|}{ Beds } \\
\cline { 2 - 5 } & number & $\mathbf{\%}$ & number & \% \\
\hline General hospitals & 256 & 23.6 & 29429 & 27.6 \\
\hline Specialty hospitals and branches & 586 & 53.9 & 21578 & 20.3 \\
\hline $\begin{array}{l}\text { Specialized Medical Centers Amana } \\
\text { hospitals }\end{array}$ & 42 & 3.9 & 5105 & 4.8 \\
\hline $\begin{array}{l}\text { Health Insurance Organization } \\
\text { hospitals* }\end{array}$ & $\mathbf{3 8}$ & $\mathbf{3 . 5}$ & $\mathbf{6 9 1 9}$ & $\mathbf{6 . 5}$ \\
\hline Educational hospitals and institutes & 19 & 1.7 & 4484 & 4.2 \\
\hline Curative Establishment hospitals & 11 & 1.0 & 1922 & 1.8 \\
\hline University hospitals & 83 & 7.6 & 33168 & 31.2 \\
\hline Other hospitals** & 52 & 4.8 & 3860 & 3.6 \\
\hline Total & $\mathbf{1 0 8 7}$ & $\mathbf{1 0 0 . 0}$ & $\mathbf{1 0 6 4 6 5}$ & $\mathbf{1 0 0 . 0}$ \\
\hline
\end{tabular}

Source: The National Information Center for Health and Population (2014).

* Cover about $59 \%$ of the population, of whom 7.5 million employees (current and retired), 15 million newborns (and below school age), 20 million pupils and students at various educational levels (see figure 3 below).

** Belonging to police, public and public business establishments. 
Figure 3: Percentage of beneficiaries of HIO services according to Law 79/1975 and amendments

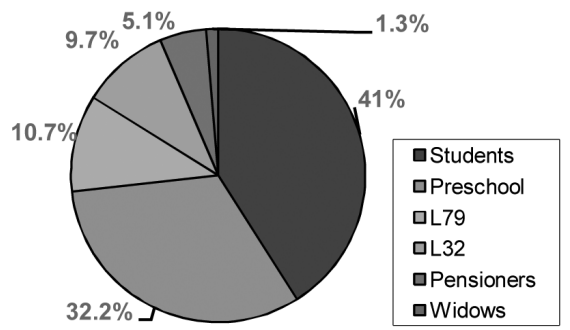

L79= Law No. 79/1975 which standardizes benefits for insured workers; L32= Law No. 32/1977 which regulates benefits for government employees as well as their colleagues in public facilities and local municipalities.

Coverage of the insured population, through the Health Insurance Organization- HIO, rose gradually from $0.5 \%$ at 1965 to $59 \%$ at the end of 2013 (Figure 4). HIO provide healthcare services through:38 hospitals, 600 clinics, 78 work related injury centers, 34 general medical committees, thousands of school clinics, as well as outsourced hospitals (640) and outpatients' clinics $(1,141)$ (Schwark and George, 2011).
Figure 4: Development of number of population covered with HIO services along 45 years

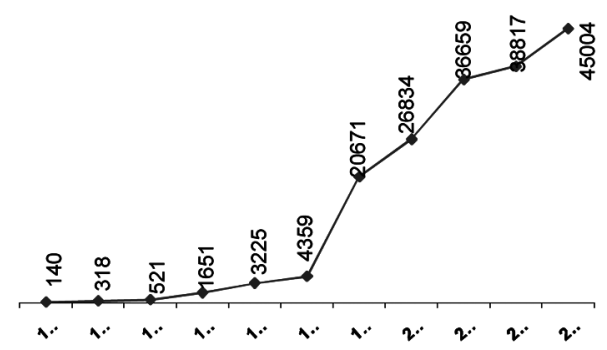

According to the social insurance scheme promulgated by the Social (and Health) Insurance Law No. 79/1975 and amendments, the occupational health surveillance is provided by the Health Insurance Organization Centers, through:

- Pre-placement medical examination $\longrightarrow$ fit to work

- Periodic medical check-ups $\longrightarrow$ early diagnosis of occupational disease/s à treatment, follow up and rehabilitation

- Evaluation of impairment/ disability $\longrightarrow$ compensation benefits.

Workers can apply personally or through the facility/enterprise physician to the nearest Health 
Insurance Organization Centre/ to the general court. The committee office to claim for compensation on their occupational injury /illness. The HIO center/office will then investigate the case; analyze its relation to occupation; decide and define the rating for physical and/or functional impairment; and determine the degree of disability giving right to compensation according to table (2) appended to Law 79 of 1975 . The Health Insurance Organization (HIO) also starts treatment of such health impairments.

In case of death due to a work-related accident (at work + commuting) the compensation provided to the victim's family is equal to his/her salary/wages for 6000 days ( $\approx 25$ working years).

Decisions regarding diagnosis of an occupational disease or injury and matters related to compensation of benefits can be appealed to a special committee of referees, the decisions of which are final but can be brought membership and procedures are organized according to the Ministerial Decree 215/1997.

In addition to evaluation of disability, the HIO is also responsible, according to Law 79/ 1975 and Law 12/ 2003 (art. 216), to carry out both pre-placement and periodic medical examinations. The HIO usually perform 125-150 thousand pre-placement medical examinations and 400-450 thousand periodic medical check-ups, annually. Both types of medical examinations are regulated by the ministerial decree no. 133/ 1983 (for pre-placement medical examination) and no. 218/ 1977 (for the periodic medical checkups).

The number of cases being compensated for their proved 'occupational illnesses' during the last 3 years, are illustrated in table 6 and figure 5, below. 
Table 6 and figure 5: Number of cases compensated for occupational illnesses during the last 3 years.

\begin{tabular}{|l|c|c|c|}
\hline \multirow{2}{*}{ Illness } & \multicolumn{3}{|c|}{ Years } \\
\cline { 2 - 4 } HCV \& HBV & $\mathbf{2 0 1 1}$ & $\mathbf{2 0 1 2}$ & $\mathbf{2 0 1 3}$ \\
\hline Pneumoconioses & 170 & 180 & 203 \\
\hline Hearing Loss & 286 & 413 & 619 \\
\hline Hormones & 3 & 9 & 19 \\
\hline Skin Eczema & 4 & 4 & 7 \\
\hline Eye Cataract & 3 & 17 & 29 \\
\hline Radiation- induced & 2 & 2 & 5 \\
\hline Other/s & 39 & 51 & 68 \\
\hline Total & $\mathbf{6 1 2}$ & $\mathbf{7 5 3}$ & $\mathbf{1 0 6 4}$ \\
\hline
\end{tabular}

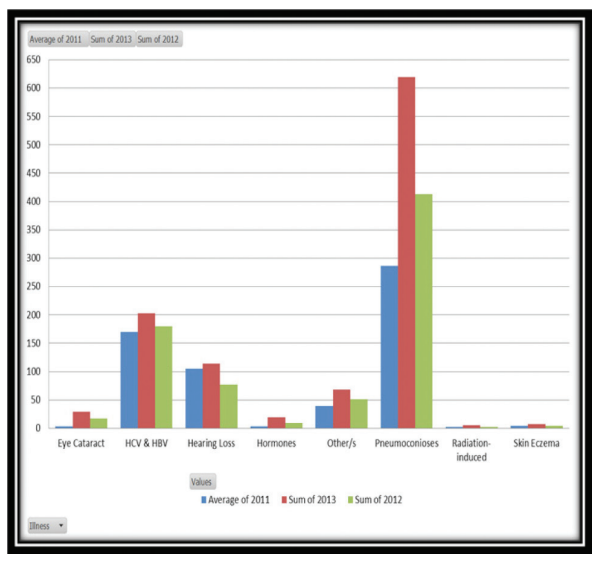

Source: The Annual Report on HIO activities- 2014 “Fifty Years of Progress".

Table 7 and figure 6, below, illustrate the number of outpatient- employees' in various HIO injury centers and clinics as well as those referred to specialists in selected years along the past 30 years.

Table 7 and figure 6: The number of outpatient- employees' in various HIO injury clinics as well as those referred to specialists in selected years along the past 30 years

\begin{tabular}{|c|c|c|}
\hline Year & Outpatient employees & Patient employees referred to specialists \\
\hline 1985 & $5,845,870$ & $2,806,834$ \\
\hline 1990 & $9,459,987$ & $5,787,569$ \\
\hline 1995 & $13,131,758$ & $10.862,370$ \\
\hline 2000 & $10,719,744$ & $12,767,116$ \\
\hline 2005 & $9,043,749$ & $13,516,428$ \\
\hline 2010 & $5,870,895$ & $11,896,018$ \\
\hline 2013 & $6,477,847$ & $12,377,451$ \\
\hline
\end{tabular}

Source: The Annual Report on HIO activities- 2014 "Fifty Years of Progress" 
Table 8, below, illustrates 33 years series of injured employees benefited from the HIO- injury centers.

Table 8: Injured employees benefited from the HIO- injury centers

\begin{tabular}{|c|c|c|c|c|c|c|c|c|c|}
\hline \multicolumn{2}{|c|}{$\begin{array}{l}\text { Years } \\
\text { Parameters }\end{array}$} & 1980 & 1985 & 1990 & 1995 & 2000 & 2005 & 2010 & 2013 \\
\hline \multicolumn{2}{|c|}{$\begin{array}{l}\text { No. of } \\
\text { centers }\end{array}$} & 30 & 32 & 36 & 48 & 62 & 61 & 72 & 73 \\
\hline \multirow{3}{*}{$\begin{array}{l}\text { No. } \\
\text { of } \\
\text { cases }\end{array}$} & New & 100,333 & 95,123 & 92,954 & 106,129 & 67,615 & 42,672 & 34,324 & 37,341 \\
\hline & Old & 215,845 & 186,648 & 232,080 & 296,145 & 177,691 & 13,351 & 114,093 & 115,247 \\
\hline & Total & 316,178 & 281,771 & 325,034 & 402,274 & 245,306 & 156,023 & 148,417 & 152,588 \\
\hline \multicolumn{2}{|c|}{$\begin{array}{l}\text { Refer to } \\
\text { specialist }\end{array}$} & 32,250 & 38,487 & 37,452 & 48,950 & 34,950 & 25,060 & 22,804 & 20,877 \\
\hline \multicolumn{2}{|c|}{$\begin{array}{l}\text { Refer to } \\
\text { hospital }\end{array}$} & 2,637 & 3,0006 & 4,872 & 5,817 & 4,970 & 4,086 & 4,234 & 4,586 \\
\hline \multicolumn{2}{|c|}{ Cured cases } & 96,845 & 90,689 & 93,363 & 99.859 & 63,472 & 38,179 & 51,770 & 31,404 \\
\hline \multicolumn{2}{|c|}{ Lost days } & $1,714,272$ & $1,166,153$ & $1,976,447$ & $2,400,002$ & $1,112,524$ & 987,082 & $1,050,579$ & $1,050,579$ \\
\hline
\end{tabular}

Source: The Annual Report on HIO activities- 2014 "Fifty Years of Progress"

\section{Shortcomings}

Based on the findings detailed above as well as previous diagnostic studies (Massoud et al., 1982, Said, 2014, Assaad and Krafft, 2013, and Sabbour, 2012) and the long experience with occupational health practices in Egypt, there are many difficulties and shortcomings preclude the comprehensive coverage with basic occupational health services. These could be summarized as follows:

- Uncovered population and labor force
- About $40 \%$ of the population are still uncovered with the HIO umbrella,

- Still, a majority of the Egyptian working population $\quad(\approx 20$ million- $75 \%$ ) are not insured for their health, mostly among temporary and informal laborers.

- Less budget allocated for health than it deserve

- Public expenditure on health represents $3-5 \%$ of the total 
public expenditure, compared to more than $10 \%$ in many countries with decent healthcare systems.

- Insufficient public, employers and employees' awareness;

- Deficient communication with employees on $\mathrm{OCH}$ services.

- Deficient practice 'Guidelines' and 'codes of practice';

- Pre-placement and periodic medical exams not well standardized.

- Weak 'voluntary compliance' versus inadequate 'obligatory enforcement';

- Inadequate policy and procedures enabling Basic $\mathrm{OCH}$ services.

- Scarce OCH physicians and nurses;

- General Practitioners (GPs) and Family physicians are not yet ready to provide Basic $\mathrm{OCH}$ services.

- Limited number and capacity of professional units;

- Deficient records and statistical reports;

\section{Conclusion}

Occupational healthcare services are essentially necessary for the Egyptian labor force that constitutes about $31.7 \%$ of the whole population and about $48.84 \%$ of those aged 15 yrs. or more. There is an urgent need of expanding the $\mathrm{OCH}$ services, which currently cover about one-quarter of the working population, to provide every employee with the basic $\mathrm{OCH}$ services as indicated by the international recommendations and the Egyptian Constitution, legislation and community necessity.

\section{Recommendations- the way forwards}

Supporting the current occupational healthcare services, aiming to cover all the employees with quality basic/ essential requirements should be the target of Egypt healthcare future policy and procedures. Collaborating efforts of the various categories of primary, secondary and tertiary healthcare services is necessary towards a real improvement in extending the coverage to the uncovered Egyptian employees. Supporting the primary healthcare services, especially in rural areas is quite important in providing frontline $\mathrm{OCH}$ services to millions of farmers and employees. 


\section{References}

1. Abo El-Ata GA and Nahmias M (2005): Occupational Safety and Health in EGYPT: A national profile. WHO and ILO- Safe work Guidelines' Series.

2. Amendment to Law 79/ 1975 (2013). Social Solidarity Minister's Decree 33/ 2013 for addition of 18 New occupational diseases to Table 1 annexed to Law 79/ 1975 at 30th May, 2013

3. Arnaout S (2006): Occupational Health in the Eastern Mediterranean Region: Challenges \& Opportunities. A paper presented in the Occupational Health Conference: 11-13 December 2006- Muscat - Oman.

4. Assaad R and Krafft C (2013): The Egypt Labor Market Panel Survey: Introducing the 2012 Round. Economic Research Forum- Working paper No. 738. Published on: www.hhh.umn. edu/people/rassaad/pdf/Assaad_Krafft.pdf

5. CAPMAS (2013): Central Agency for Public Mobilization and Statistics- Labor Force Survey 2012. Cairo, Egypt: CAPMAS.

6. CAPMAS (2014): Central Agency for Public Mobilization and Statistics. Egypt in Figures 2014. Issued in March 2014, CAPMAS at Cairo- Egypt.

7. Economist Intelligence Unit. Country Profile: Egypt. 2003. P. 17

8. Farag M (2012): National Health Accounts (NHA) in Egypt: Overview and Key Findings. A paper presented at Global Health Council in June 16, 2011. www.HealthSystems2020.org

9. Health Insurance Organization- HIO (2014). The annual Report on HIO activities: 50 Years of Progress. Electronic copy on: www.hio.gov. eg
10. International Youth Foundation- IYF (2013). A labor market assessment of Post-revolution Egypt: Opportunities and Challenges for the Future- January 2012-March 2013.

11. Massoud A,Faris R, Hussein Mand Abdel Kawy AM (1982): An epidemiologic approach to occupational health problems in Egypt. Scand J Work Environ Health 1982; 8 (1): 40-43. Downloaded from www. sjweh.fi on April 23, 2014.

12. Sabbour SM (2012): Health system and health services in Egypt. A presentation in the Annual Conference of Community, Environment and Occupational Medicine Department at Faculty of Medicine - Ain Shams University, EGYPT.

13. Said M (2014): Labour market developments and policies in Egypt. Presented in Egyptian Forum for Youth Employment Promotion and Torino Process 2014. Safir Hotel Cairo, March 24,2014

14. Schwark T and George M (2011):The Health Insurance Organization of Egypt: Utilization and Case Management. A paper presented at Global Health Council in June 16, 2011. www.HealthSystems2020 .org

15. The Annual Report on HIO activities- 2014 "Fifty Years of Progress". The Health Insurance Organization- Egypt.

16. The National Information Center for Health and Population (2014). Healthcare services in Egypt.

17. WHO. World Health Organization Report, 2003. www.who.int

18. WHO. World Health Organization Report. Core Health Indicators: Egypt. 2003. www.who.int

19. World Bank (2013): Labor force - total in Egypt - Trading Economics. In: www. tradingeconomics.com/egypt/labor-force-totalwb-data.html. 